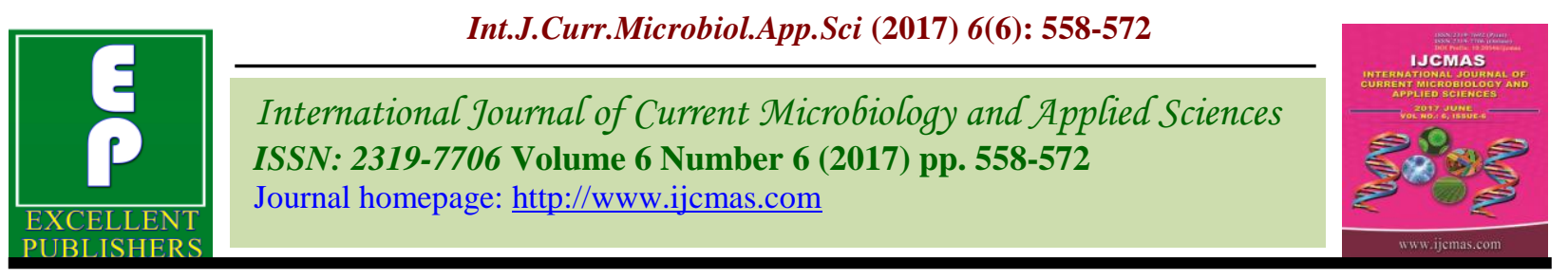

Original Research Article

https://doi.org/10.20546/ijcmas.2017.606.066

\title{
Baetidae (Ephemeroptera: Insecta) as Biological Indicators of Environmental Degradation in Tamiraparani and Vaigai River Basins of Southern Western Ghats, India
}

\author{
T. Kubendran ${ }^{1 *}$, C. Selvakumar ${ }^{2}$, Avtar Kaur Sidhu, Akhil Nair $^{1}$ and S. Murali Krishnan ${ }^{3}$ \\ ${ }^{1}$ High Altitude Regional Centre, Zoological Survey of India, Saproon, \\ Solan - 721232, Himachal Pradesh, India \\ ${ }^{2}$ Zoological Survey of India, New Alipore - 700 053, Kolkata, West Bengal, India \\ ${ }^{3}$ National Centre of Excellence on Statistical and Mathematical Modeling on Bioresources \\ Management- MHRD, Thiagarajar College, Madurai-625 009, Tamil Nadu, India \\ *Corresponding author
}

\section{A B S T R A C T}

\begin{tabular}{|l|}
\hline Ke y w o r d s \\
Ephemeroptera, \\
Baetidae, \\
Bioassessment, \\
Bioindicator, \\
Western Ghats, \\
India. \\
\hline Article Info \\
\hline Accepted: \\
04 May 2017 \\
Available Online: \\
10 June 2017 \\
\hline
\end{tabular}

Biomonitoring of the Ephemeroptera (Family: Baetidae) was undertaken at species level in the Tamiraparani (Tirunelveli) and Vaigai (Theni) river basins of southern India. A total of 1,359 baetids were collected from three times from ten sampling sites, representing an environmental gradient. The mesohabitats of sixteen Baetidae species was described and their responses to environmental degradation and water chemistry were evaluated by means of species richness and abundance and the data was subjected to multivariate analysis (Canonical Correspondence Analysis), in order to assess their potential capacity as indicators of these impacts. Most species were found predominantly associated with stony substrates, but some were associated with grasses, and two species were found predominantly in lentic water bodies. Species distributions were influenced by the environmental gradient. Based on the CCA ordination, pristine and the most impaired areas were identified for each spices so as were found in therefore enabling us to establish the sensitivity of each species.

\section{Introduction}

Freshwater habitats are being subjected to increased levels of human disturbance throughout the world (Saunders et al., 2002). A recent assessment of the status of inland water ecosystems shows that globally most threatened river catchments are to be found in the Indian subcontinent. Biological monitoring is a central component of water resource management throughout the world (Rosenberg and Resh, 1993; Barbour et al.,
1999). The systematic development and testing of rapid bioassessment tools on river basins using benthic aquatic insects in Brazil is recent (Buss et al., 2002; Buss, 2001; Callisto et al., 1998; Silveira et al., 2005) and due to limited knowledge of the taxonomy and distribution of mayflies in India, these studies have generally used supraspecific taxonomic levels. 
Aquatic insects are ideal indicators of pollution (Dudgeon, 1999) aquatic insects also inhabit vital position in the food chain of aquatic systems and therefore can be used to make estimates of ecosystem health. Analysis of aquatic insect assemblages is also lot of time and cost efficient compared to chemical and physical assessments of water quality (Bode et al., 1995; EEA, 2007).

In temperate streams it is very well documented that the changes in catchment land use results in the loss or a change in diversity of invertebrates and fishes (Corkum, 1989; Allan, 1995; Vinson and Hawkins, 1998). Similarly, in tropical Asia, though it is known that deforestation of the catchment affects fish populations (Dudgeon, 1992; 1999) the impact of catchment land use on the stream insect communities is poorly understood.

In freshwater biodiversity hotspots like the Western Ghats, no information is available on this topic. Such information is very important to understand the impact of ongoing landscape transformations on the biodiversity of rivers in general and insect communities in particular. This information will also aid in developing conservation strategies for the riverine ecosystems of tropical biodiversity hotspots such as the Western Ghats (Subramanian et al., 2005).

The purpose of this study was to determine the specific requirements of species of family Baetidae and evaluate their potential use as indicator species for assessing environmental degradation in the Western Ghats river systems and to describe the mesohabitat and to assess their responses to environmental degradation and hydro-chemistry by means of biological measures (richness and abundance) and multivariate analysis (Canonical Correspondence Analysis), in order to evaluate their potential capacity as indicators of these impacts.

\section{Materials and Methods}

\section{Study area}

This study was carried out at the Tamiraparani and Vaigai rivers, which is the two major river basins of the southern Western Ghats. Tamiraparani, a major east flowing river with catchment area of 5482 $\mathrm{km} 2$ is a medium sized river basin in India. It originates from the Pothigai hills of KalakadMundanthurai Tiger Reserve (KMTR) of the Western Ghats $\left(8^{\circ} 42^{\prime} \mathrm{N}\right.$ and $\left.77.15^{\circ} 24^{\prime} \mathrm{E}\right)$ at an altitude of $2074 \mathrm{~m}$. Tamiaraparani river basin benefits from both the north-east and south-west monsoons (Martin et al., 2000). The Vaigai river is one of the major river system in Madurai, Tamil Nadu state of southern India. It originates in the Periyar Plateau of the Western Ghats range, and flows northeast through the Cambam Valley, which lies between the Palni hills to the north and the Varushanad hills to the south (Martin et al., 2000).

Larval forms of Baetidae species were sampled along with data on physical, chemical and other environmental variables at ten sites on Tamiraparani and Vaigai river basins. Two sites are third order streams and three sites are fourth order river, and all sites were at the altitudes between 60 and 150 m.a.s.l. Sites were chosen to represent an environmental gradient from a pristine area such as diversity of species (site A, B, F and $\mathrm{G})$ to most impaired (site $\mathrm{E}$ and I). The four classes are: site A and B (Class 1), sites C, D and $\mathrm{E}$ (class 2), sites $\mathrm{F}$ and $\mathrm{G}$ (class 3 ), and sites $\mathrm{H}$, I and $\mathrm{J}$ (class 4). Class 1 and 3 are located at upstream and class 2 and 4 are located in downstream from the Tamiraparani and Vaigai river basins. Class 1 and 3 are chosen as a reference sites because of its dense riparian vegetation ( $80 \%$ stream cover). Class 2 and 4 sites have disturbances caused by the tourists and pilgrims thronging them during festivals and ceremonies. 


\section{Field and laboratory procedures}

\section{Species collection and identification}

The larvae of Baetidae species were collected by kick net (mesh size: 0.5 to $1.0 \mathrm{~mm}$ ) sampling (Balasubramanian et al., 1992). The duration of each kick net operation was 2 minutes. The substratum viz., bed rocks, boulders and cobbles was vigorously disturbed strictly restricted to one $\mathrm{m}^{2}$ area. All specimens from the net surface were carefully collected without any morphological damage using fine forceps or brush and preserved in 80\% Ethyl alcohol immediately. Sampling was performed on for two years 2010-2011. The collected samples were brought to laboratory and identified upto genus and species level was carried out by done using published taxonomical literature pertaining to of the Western Ghats, India (Sivaramakrishnan et al., 2009; Selvakumar et al., 2012; Kubendran et al., 2014; 2015).

\section{Analysis of physico-chemical factors}

Recording of selected river characteristics like order of the stream, nature of the eco-region, substrate composition and a few physicochemical parameters like wet width, depth, water current as well as water temperature were done at the sampling sites during sampling (Table 5). River characteristics were evaluated qualitatively by following visual observation and description.

\section{Substrate index}

Substrates were classified by using (Jowett et al., 1991). The following criteria: $<0.5 \mathrm{~mm}$ for mud/silt, 0.5-2 mm for sand, 2-64 $\mathrm{mm}$ for gravel, $65-256 \mathrm{~mm}$ for cobbles, and $>256 \mathrm{~mm}$ for boulders. For statistical analysis, substrate composition was converted to a substrate index (Suren, 1996) as explained below: Substrate Index $=(0.07 \times$ \% boulder $)+(0.06$ $\mathrm{x} \%$ cobble $)+(0.05 \times \%$ gravel $)+(0.04 \times \%$ sand $)+(0.03 \times \% \mathrm{mud} / \mathrm{silt})$ (Jowett et al., 1991).

\section{Data analysis}

The structure of the Baetidae assemblage was evaluated by species richness and abundance. CCA was performed to determine relationships between environmental variables and the respective biotic components. Diversity indices and CCA were performed carried out by the PAST software (Hammer $e t$ al., 2001).

\section{Results and Discussion}

Total of 1,359 individuals corresponding belonging to nine genera belonging to sixteen species belonging to nine genera were recorded in this study (Tables 1 and 2).

The representation of physico-chemical variables of study sites are listed in table 5 . The tropical structure of the baetid assemblage was varying among the sampling periods. The total number of individuals was appreciably more at the post-monsoon, intermediate at the end of the pre-monsoon and minimum at the dry season. The most abundant species are LabioBaetis soldani and NigroBaetis paramakalyani collected in the sites are 161 and 160 individuals respectively. $L$. verum and $L$. pulchellum represented with the least abundance during investigation period.

\section{Substrate preference of Baetidae species}

Most Species such as Baetis acceptus, B. conservatus, $\quad B . \quad$ frequentus, $I$. michaelohubbardi, LabioBaetis geminatus, $L$. pulchellum, L. soldani, L. jacobusi, and $L$. vera were found predominantly associated with pebbles substrates, but $L$. geminatus, $L$. pulchellum, L. soldani and N. paramakalyani 
some were predominantly associated with grasses, (90), two species $C$. ceylonensis and $C$. similis were primarily attached with rocks and two species namely $C$. bimaculatum and $P$. regularum were found in pool litter substrate (40). Absence of all species in fine sediment substrate sites is a notable point (Tables 3, 4 and 7).

\section{Site preference of Baetidae species}

Baetid species richness followed the gradient of environment and water quality in the Tamiraparani and Vaigai river basins. Totally 14 baetid species were associated to sites of classes 1 and 3, and one species (46 individuals of L. geminatus) and two species of ( $C$. bimaculatum and $P$. regularum) were found in the most impaired site. Class 4 site had species richness within this limit (five species). Simson and Shanon index were higher in site $F(0.9061,2.501)$ and $H$ $(0.9044,2.496)$ compare to other sites of intermediate integrity (Table 6).

\section{Canonical Correspondence Analysis (CCA)}

In order to determine the specific environmental parameter that associated with Baetid species distribution and CCA was performed (Fig. 1). The diversity of the baetids of the analyzed communities was correlated with the physicochemical parameters. The most influencing factor was the concentration of dissolved oxygen. Obviously, species richness was high in the sampling sites towards upstream where the dissolved oxygen content was higher. Based on the CCA plot for the sites, the two River basins have been classified into four reaches among which the first reach had good water quality marked by the presence of higher species diversity, the second level of sites had disturbances caused by the tourists and pilgrims thronging them during festivals and ceremonies. The two sites in this reach were represented by two species LabioBaetis sp. and NigroBaetis sp. The third and fourth reaches had minimal baetid representation which clearly indicated the gradual increase in pollution load and the corresponding deteriorated water quality. Localities that were towards the last reach had only two species namely $C$. bimaculatum and $P$. regularum that usually inhabit localities impacted by some type of pollution.

Water temperature of Thalaianai and Valiparai is one of the most important physical characteristics of ecosystem. It affects a number of water quality parameters that is one of the concerns using for bathing, washing the clothes and pilgrims activities. The chemical and biological reaction rates increase with increased water temperature. The $\mathrm{pH}$ of water affects the normal physiological functions of aquatic organisms, including the exchange of ions with the water and respiration. Such important physiological processes operate normally in most aquatic biota under a relatively wide $\mathrm{pH}$ range (e.g. 6.5-8.5 pH units). The significant change in $\mathrm{pH}$ value is due to using the detergents and bathing soaps and also drastically changes in $\mathrm{pH}$ of time due to the exposure of air, biological activity and temperature. The higher values of $\mathrm{pH}$ recorded in Kurangani could be attributed to increased primary productivity wherein carbonates, sulfate, nitrates and phosphates are converted to hydroxyl ions. Dissolved oxygen analysis measures the amount of gaseous oxygen $\left(\mathrm{O}_{2}\right)$ dissolved in an aqueous solution. The dissolved oxygen was less $6.2 \mathrm{mg} / \mathrm{L}^{-1}$ in Thiruvedakam and higher value $9.02 \mathrm{mg} / \mathrm{L}^{-1}$ in Kurangani. Dissolved oxygen levels change and vary according to the time of day, the weather and the temperature. Its presence is essential in aquatic ecosystem in bringing out various bio- chemical changes and its effect on metabolic activities of organism. $\mathrm{CO}_{2}$ values are within the permissible limits. 
Beyond permissible limit taste, corrosion and palatability of water is affected. Besides imparting salty taste water high level of total solids, total suspended solids and dissolved solids have deleterious effects on metallic pipes and structure as well as on agricultural plants are also reported (Balachandran et al., 2011; Kubendran and Ramesh, 2016a,b).

In this study, out of 16 species of Baetidae, 14 were associated predominantly with pebble substrates, 9 species with grasses and wood debris, 8 species with leaf litter, 7 species with rocky substrate and 2 species with pool areas. This predominantly association with pebbles substrates may be explained by their main food source. Sivaramakrishnan and Venkataraman (1987) categorized the functional feeding groups of a few Baetidae species. The above mentioned species were assigned to the scraper functional feeding group. Studies exclusively on Baetidae in south-east Brazil indicate that these species have a strong negative effect on the quantity periphyton and sediment (Moulton et al., 2004), suggesting that these species are important herbivores in this region.

Fig.1 Canonical Correspondence Analysis (CCA) based on the Baetidae diversity and physico-chemical parameters

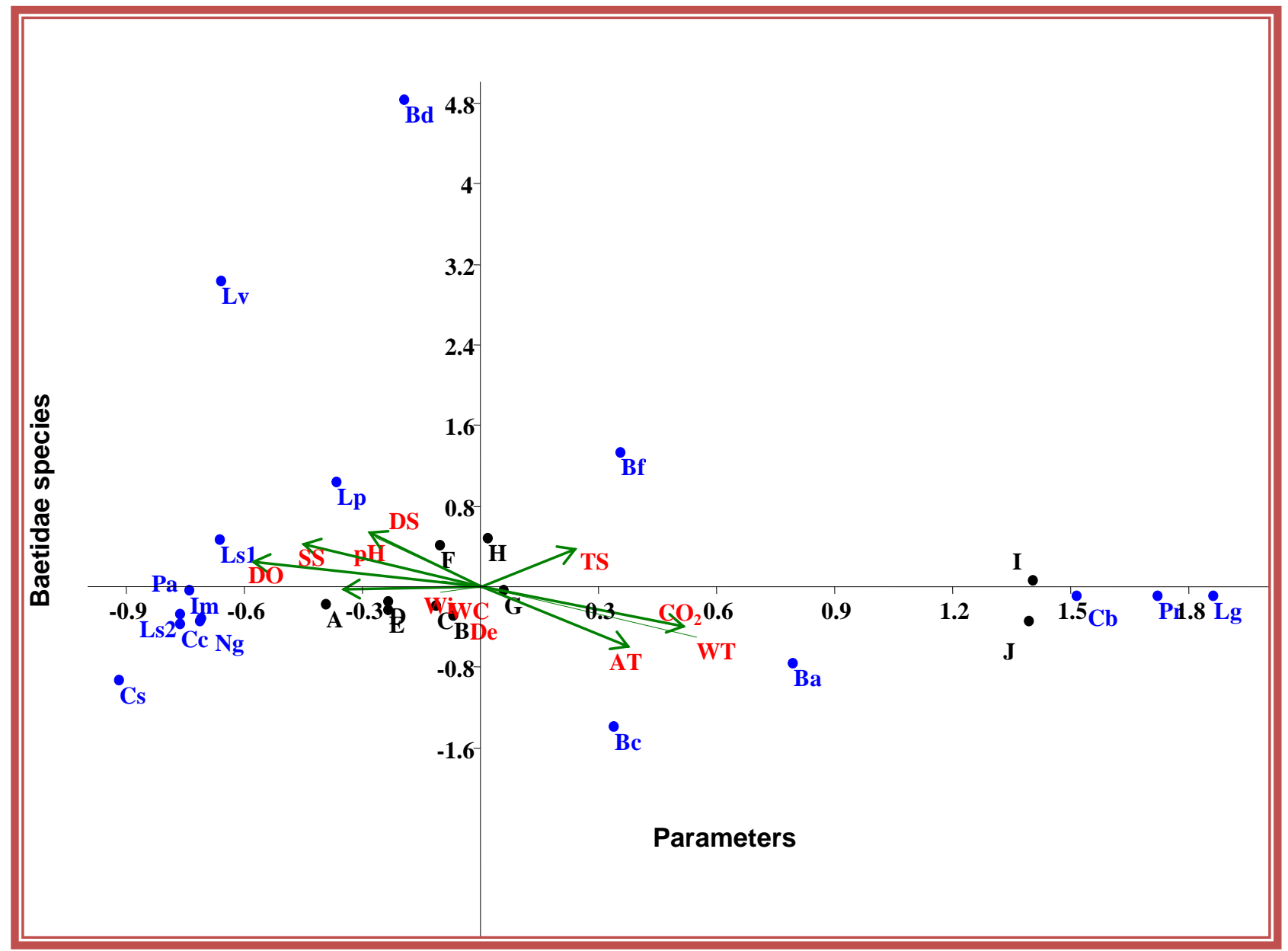


Table.1 Baetid species at each sampling site and total number of individuals collected in the southern Western Ghats during 2010-2011

\begin{tabular}{|c|c|c|c|c|c|c|c|c|c|c|c|}
\hline Particulars & A & B & $\mathbf{C}$ & D & $\mathbf{E}$ & $\mathbf{F}$ & $\mathbf{G}$ & $\mathbf{H}$ & I & $\mathbf{J}$ & Total \\
\hline Baetis acceptus & 4 & 5 & 8 & 3 & 5 & 3 & 3 & 6 & 3 & 5 & 45 \\
\hline Baetis conservatus & 2 & 3 & 4 & 1 & 5 & 2 & 2 & 2 & 0 & 3 & 24 \\
\hline Baetis sp. & 0 & 0 & 0 & 0 & 0 & 17 & 1 & 10 & 0 & 0 & 28 \\
\hline Baetis frequentus & 1 & 3 & 4 & 1 & 5 & 48 & 22 & 30 & 5 & 0 & 119 \\
\hline Cloeon bimaculatum & 0 & 0 & 6 & 4 & 12 & 11 & 7 & 5 & 10 & 7 & 62 \\
\hline Chopralla ceylonensis & 21 & 15 & 8 & 4 & 19 & 24 & 9 & 8 & 0 & 0 & 108 \\
\hline Chopralla similis & 11 & 4 & 5 & 2 & 22 & 15 & 6 & 1 & 0 & 0 & 66 \\
\hline IndoBaetis michaelohubbardi & 20 & 12 & 15 & 7 & 25 & 28 & 1 & 22 & 0 & 0 & 130 \\
\hline LabioBaetis geminatus & 1 & 8 & 4 & 1 & 2 & 4 & 4 & 8 & 9 & 5 & 46 \\
\hline LabioBaetis pulchellum & 1 & 1 & 2 & 4 & 1 & 2 & 1 & 2 & 0 & 0 & 14 \\
\hline LabioBaetis sp. & 5 & 1 & 11 & 3 & 30 & 25 & 15 & 22 & 0 & 0 & 112 \\
\hline LabioBaetis soldani & 18 & 11 & 24 & 22 & 40 & 21 & 6 & 19 & 0 & 0 & 161 \\
\hline Liebebiella vera & 3 & 0 & 0 & 0 & 0 & 4 & 0 & 5 & 0 & 0 & 12 \\
\hline NigroBaetis sp. & 30 & 10 & 12 & 10 & 50 & 23 & 5 & 20 & 0 & 0 & 160 \\
\hline Cloeon sp. & 8 & 8 & 12 & 12 & 55 & 25 & 6 & 10 & 0 & 0 & 136 \\
\hline Procloeon regularum & 10 & 5 & 3 & 5 & 5 & 22 & 4 & 20 & 30 & 32 & 136 \\
\hline
\end{tabular}

A- Panathertham; B- Kallar; C- Sorimuthu Ayyanar river; D- Agasthiar falls; E- Thalaianai; F- Kurangani; G- Suruli falls; H- Valiparai; I- Thiruvedagam and J- Peranai 
Table.2 Percent of occurrence of each Baetid species at each sampling site in the southern Western Ghats during 2010-2011

\begin{tabular}{|c|c|c|c|c|c|c|c|c|c|c|}
\hline \multirow{3}{*}{ Particulars } & \multicolumn{10}{|c|}{ Percent of sampling site (\%) } \\
\hline & \multicolumn{2}{|c|}{ Class 1} & \multicolumn{3}{|c|}{ Class 2} & \multicolumn{2}{|c|}{ Class 3} & \multicolumn{3}{|c|}{ Class 4} \\
\hline & $\mathbf{A}$ & B & $\mathbf{C}$ & D & $\mathbf{E}$ & $\mathbf{F}$ & $\mathbf{G}$ & $\mathbf{H}$ & $\mathbf{I}$ & $\mathbf{J}$ \\
\hline Baetis acceptus & 8.88 & 11.11 & 17.77 & 6.66 & 11.11 & 6.66 & 6.66 & 13.33 & 6.66 & 11.11 \\
\hline Baetis conservatus & 8.33 & 12.5 & 16.66 & 4.22 & 20.83 & 8.33 & 8.33 & 8.33 & 0 & 12.5 \\
\hline Baetis sp. & 0 & 0 & 0 & 0 & 0 & 60.71 & 3.57 & 35.71 & 0 & 0 \\
\hline Baetis frequentus & 0.8 & 2.52 & 3.33 & 0.8 & 4.2 & 40.33 & 18.48 & 25.21 & 4.2 & 0 \\
\hline Cloeon bimaculatum & 0 & 0 & 9.66 & 6.45 & 19.35 & 17.74 & 11.29 & 8.06 & 16.12 & 11.29 \\
\hline Chopralla ceylonensis & 19.44 & 13.88 & 7.4 & 3.7 & 17.59 & 22.22 & 8.33 & 7.4 & 0 & 0 \\
\hline Chopralla similis & 16.6 & 6 & 7.57 & 3.3 & 33.33 & 22.72 & 9.9 & 1.51 & 0 & 0 \\
\hline IndoBaetis michaelohubbardi & 15.38 & 9.23 & 11.53 & 5.38 & 19.23 & 21.53 & 0.76 & 16.92 & 0 & 0 \\
\hline LabioBaetis geminatus & 2.17 & 17.39 & 8.69 & 2.17 & 4.34 & 8.69 & 8.69 & 17.34 & 19.56 & 10.86 \\
\hline LabioBaetis pulchellum & 7.14 & 7.14 & 14.28 & 28.36 & 7.14 & 14.28 & 7.14 & 14.28 & 0 & 0 \\
\hline LabioBaetis sp. & 4.46 & 0.89 & 9.82 & 2.67 & 26.78 & 22.32 & 13.92 & 19.69 & 0 & 0 \\
\hline LabioBaetis soldani & 11.18 & 6.83 & 14.9 & 13.66 & 24.84 & 13.04 & 3.72 & 11.8 & 0 & 0 \\
\hline Liebebiella vera & 25 & 0 & 0 & 0 & 0 & 33.3 & 0 & 41.6 & 0 & 0 \\
\hline NigroBaetis sp. & 18.75 & 6.25 & 7.5 & 6.25 & 31.25 & 14.37 & 3.12 & 12.5 & 0 & 0 \\
\hline Cloeon sp. & 5.8 & 5.8 & 8.82 & 8.82 & 40.44 & 18.38 & 4.4 & 7.35 & 0 & 0 \\
\hline Procloeon regularum & 7.35 & 3.67 & 2.2 & 3.67 & 3.67 & 16.17 & 2.94 & 14.75 & 22.05 & 23.55 \\
\hline
\end{tabular}


Table.3 Substrate preference and total number of Baetid individuals collected in the ten sampling sites in the southern Western Ghats

\begin{tabular}{|c|c|c|c|c|c|c|c|}
\hline Particulars & Rock & Pebbles & Grasses & wood debris & leaf litters & Pool & TOTAL \\
\hline Baetis acceptus & 3 & 15 & 20 & 5 & 2 & 0 & 45 \\
\hline Baetis conservatus & 0 & 12 & 9 & 2 & 1 & 0 & 24 \\
\hline Baetis sp. & 0 & 25 & 0 & 3 & 0 & 0 & 28 \\
\hline Baetis frequentus & 10 & 44 & 35 & 16 & 14 & 0 & 119 \\
\hline Cloeon bimaculatum & 15 & 0 & 27 & 0 & 0 & 20 & 62 \\
\hline Chopralla ceylonensis & 44 & 64 & 0 & 0 & 0 & 0 & 108 \\
\hline Chopralla similis & 33 & 33 & 0 & 0 & 0 & 0 & 66 \\
\hline IndoBaetis michaelohubbardi & 0 & 70 & 0 & 33 & 27 & 0 & 130 \\
\hline LabioBaetis geminatus & 0 & 10 & 36 & 0 & 0 & 0 & 46 \\
\hline LabioBaetis pulchellum & 0 & 14 & 0 & 0 & 0 & 0 & 14 \\
\hline LabioBaetis sp. & 0 & 20 & 70 & 12 & 10 & 0 & 112 \\
\hline LabioBaetis soldani & 0 & 40 & 80 & 20 & 21 & 0 & 161 \\
\hline Liebebiella vera & 0 & 12 & 0 & 0 & 0 & 0 & 12 \\
\hline NigroBaetis sp. & 0 & 40 & 90 & 20 & 10 & 0 & 160 \\
\hline Cloeon sp. & 10 & 80 & 40 & 3 & 3 & 0 & 136 \\
\hline Procloeon regularum & 96 & 0 & 0 & 0 & 0 & 40 & 136 \\
\hline \multicolumn{7}{|c|}{ TOTAL } & 1359 \\
\hline
\end{tabular}


Table.4 Baetid species percent per substrate and total number of individuals collected in the ten sampling sites in the southern Western Ghats

\begin{tabular}{|c|c|c|c|c|c|c|c|}
\hline \multirow[b]{2}{*}{ Particulars } & \multicolumn{7}{|c|}{ Percent of substrates (\%) } \\
\hline & Rock & Pebbles & Grasses & $\begin{array}{c}\text { wood } \\
\text { debris }\end{array}$ & $\begin{array}{c}\text { leaf } \\
\text { litters }\end{array}$ & Pool & $\begin{array}{l}\text { Total no of } \\
\text { Individuals }\end{array}$ \\
\hline Baetis acceptus & 6.66 & 33.33 & 44.44 & 11.11 & 4.44 & 0 & 45 \\
\hline Baetis conservatus & 0 & 50 & 37.5 & 8.33 & 4.16 & 0 & 24 \\
\hline Baetis sp. & 0 & 89.28 & 0 & 10.71 & 0 & 0 & 28 \\
\hline Baetis frequentus & 8.4 & 36.97 & 29.41 & 13.44 & 11.76 & 0 & 119 \\
\hline Cloeon bimaculatum & 24.19 & 0 & 43.54 & 0 & 0 & 32.25 & 62 \\
\hline Chopralla ceylonensis & 40.74 & 59.25 & 0 & 0 & 0 & 0 & 108 \\
\hline Chopralla similis & 50 & 50 & 0 & 0 & 0 & 0 & 66 \\
\hline IndoBaetis michaelohubbardi & 0 & 53.84 & 0 & 25.28 & 20.76 & 0 & 130 \\
\hline LabioBaetis geminatus & 0 & 21.73 & 78.26 & 0 & 0 & 0 & 46 \\
\hline LabioBaetis pulchellum & 0 & 100 & 0 & 0 & 0 & 0 & 14 \\
\hline LabioBaetis sp. & 0 & 17.85 & 62.5 & 10.71 & 8.92 & 0 & 112 \\
\hline LabioBaetis soldani & 0 & 24.84 & 49.68 & 12.42 & 13.04 & 0 & 161 \\
\hline Liebebiella vera & 0 & 100 & 0 & 0 & 0 & 0 & 12 \\
\hline NigroBaetis sp. & 0 & 25 & 56.25 & 12.5 & 6.25 & 0 & 160 \\
\hline Cloeon sp. & 7.35 & 58.82 & 29.41 & 2.2 & 2.2 & 0 & 136 \\
\hline Procloeon regularum & 70.58 & 0 & 0 & 0 & 0 & 29.42 & 136 \\
\hline & & & & & & TOTAL & 1359 \\
\hline
\end{tabular}


Table.5 Physico- chemical parameters of selected sits of southern Western Ghats during 2010-2011

\begin{tabular}{|c|c|c|c|c|c|c|c|c|c|c|}
\hline & $\mathbf{A}$ & B & $\mathbf{C}$ & D & $\mathbf{E}$ & $\mathbf{F}$ & $\mathbf{G}$ & $\mathbf{H}$ & $\mathbf{I}$ & $\mathbf{J}$ \\
\hline Water Temperature $\left({ }^{\circ} \mathrm{C}\right)$ & 21 & 23 & 21 & 22 & 21 & 21 & 22 & 21 & 22 & 23 \\
\hline Air Temperature $\left({ }^{\circ} \mathrm{C}\right)$ & 26 & 27 & 24 & 24 & 25 & 23 & 24 & 24 & 26 & 26 \\
\hline Water Current (m/sec) & 7 & 7.85 & 7.65 & 6.83 & 7.2 & 7.4 & 6.83 & 7.65 & 6.5 & 7.8 \\
\hline Depth (M) & 0.3 & 0.6 & 0.8 & 0.6 & 0.8 & 0.5 & 0.6 & 0.8 & 0.5 & 0.6 \\
\hline Dissolved oxygen (mg/L) & 7.64 & 7.79 & 8.5 & 8.2 & 8 & 9.07 & 8.2 & 8.5 & 6.2 & 8 \\
\hline Total Solids & 0.4 & 0.55 & 0.6 & 0.5 & 0.09 & 0.56 & 0.5 & 0.6 & 0.56 & 0.5 \\
\hline Dissolved Solids & 0.04 & 0.05 & 0.04 & 0.02 & 0.01 & 0.1 & 0.02 & 0.04 & 0.02 & 0.02 \\
\hline Suspended Solids & 0.36 & 0.45 & 0.56 & 0.06 & 0.08 & 0.46 & 0.06 & 0.56 & 0.06 & 0.04 \\
\hline Substrate Index & 5.8 & 5.6 & 5.8 & 5.6 & 5.7 & 5.8 & 5.5 & 5.9 & 5.3 & 5.7 \\
\hline
\end{tabular}

Table.6 Taxa richness, individuals, Simpson index, Shannon index and evenness values for the sites studied in the southern Western Ghats

\begin{tabular}{|l|c|c|c|c|c|c|c|c|c|c|}
\hline & A & B & C & D & E & F & G & H & I & J \\
\hline Taxa richness & 14 & 13 & 14 & 14 & 14 & 16 & 15 & 16 & 5 & 5 \\
\hline Individuals & 135 & 86 & 118 & 79 & 276 & 274 & 92 & 190 & 57 & 52 \\
\hline Simpson & 0.8679 & 0.8913 & 0.8951 & 0.8598 & 0.8721 & 0.9061 & 0.8795 & 0.9044 & 0.6568 & 0.5814 \\
\hline Shannon & 2.222 & 2.346 & 2.429 & 2.254 & 2.238 & 2.501 & 2.369 & 2.496 & 1.303 & 1.184 \\
\hline Evenness & 0.6591 & 0.8031 & 0.8107 & 0.6803 & 0.6699 & 0.7622 & 0.7122 & 0.7581 & 0.7361 & 0.6533 \\
\hline
\end{tabular}

A- Panathertham; B- Kallar; C- Sorimuthu Ayyanar river; D- Agasthiar falls; E- Thalaianai; F- Kurangani; G- Suruli falls; H- Valiparai; I- Thiruvedagam and J- Peranai 
Table.7 Summary of the preferred substrate, morphologic adaptations and tolerance to the measured stress of the sixteen Baetidae species analyzed in southern Western Ghats

\begin{tabular}{|c|c|c|c|c|}
\hline S.No & Name of the species & Preferred substrate & $\begin{array}{l}\text { Habit and morphologic } \\
\text { adaptation to live in the substrate }\end{array}$ & $\begin{array}{l}\text { Tolerance to the } \\
\text { measured stress }\end{array}$ \\
\hline 2 & Baetis conservatus & Pebbles & $\begin{array}{l}\text { Small body, live between pebbles } \\
\text { attaché algae and pebbles }\end{array}$ & Somewhat sensitive \\
\hline 3 & Baetis sp. & Pebbles & $\begin{array}{l}\text { Small body, live between } \\
\text { Stenopsyche nest and Rock }\end{array}$ & Very sensitive \\
\hline 4 & Baetis frequentus & Pebbles and grasses & Small body, Swimmers & Somewhat sensitive \\
\hline 6 & Chopralla ceylonensis & Rock and Pebbles & Small body, long claw dentecles & Somewhat sensitive \\
\hline 7 & Chopralla similis & Rock and Pebbles & Small body, long claw dentecles & Somewhat sensitive \\
\hline 8 & IndoBaetis michaelohubbardi & Pebbles and Wood debris & Small body & Very sensitive \\
\hline 9 & LabioBaetis geminatus & Grasses & Small body, Swimmers & Somewhat sensitive \\
\hline 10 & LabioBaetis pulchellum & pebbles & $\begin{array}{l}\text { Small body, live between pebbles } \\
\text { attach algae and pebbles }\end{array}$ & Somewhat sensitive \\
\hline 14 & NigroBaetis sp. & Grasses and Pebbles & $\begin{array}{l}\text { Small body, Swimmers, long caudal } \\
\text { filaments }\end{array}$ & Very sensitive \\
\hline 15 & Cloeon sp. & Pebbles and Grasses & Small body, reduced caudal filament & Very sensitive \\
\hline 16 & Procloeon regularum & Pool and Grasses & $\begin{array}{l}\text { Small to medium body, Swimmers, } \\
\text { long and pointed claw, live between } \\
\text { grass and algae }\end{array}$ & Tolerant \\
\hline
\end{tabular}




\section{Substrate preference}

Baetid species of L. pulchellum (100\%) followed by Baetis sp. (89.28\%), C. ceylonensis (58.25\%), and $I$. michaelohubbardi (53.84\%) occurred preferentially in pebbles substrates and exhibit morphologic adaptations to resist hydraulic stress such as the presence of long caudal filament in the tail of Nigro Baetis sp. Salles et al., (2003) found one of $C$. dasilvai (as Cryptonympha sp.) in riffle areas, corroborating that this species probably occurs preferentially in this habitat. The species $L$. geminatus was found associated to grass substrate $(78.28 \%)$, and to a lesser in pebbles areas $(21.73 \%)$. The species $C$. ceylonensis and $C$. similis, in contrast to the other species that occupied rocky substrate, do not show morphologic characteristics to resist fast water current (on the contrary, larvae have narrow legs and claws without denticules). In field observations suggest that C. bimaculatum, when associated to pool areas, live in areas less exposed to the water flow.

The field observations suggest that $C$. bimaculatum, when associated to pool areas, live in areas less exposed to the water flow. But, the species I. michaelohubbardi was found predominantly on the wood debris and leaf litter. These findings are in accordance with Francischetti et al., (2004).The species I. michaelohubbardi was found predominantly in wood debris and leaf litter substrate. These findings are in accordance with Francischetti et al., (2004), I. michaelohubbardi was associated to areas with slow water flow, frequently living beneath litter, while the robust species $L$. soldani is more often found associated to pebbles substrate influenced by faster water current. $C$. bimaculatum $(32.25 \%)$ and $P$. regularum $(29.42 \%)$ were often occurred on pool substrates, but they were also found in rocky areas. Little is known about the biology of both species, but the field observations indicate that species of C. bimaculatum seems to be more often associated to pool areas.

\section{Site preference of Baetidae species}

The higher abundance of baetids in intermediately impaired areas corroborate the classification of the family Baetidae as 'somewhat sensitive' in biotic indices worldwide (Armitage et al., 1983; Hilsenhoff, 1988; Buss and Salles, 2007). However, considering the taxa richness, all sixteen species occurred in sites of classes 1 and 3, while richness in the most impaired site was low (and often with low abundance). Therefore, taxa richness of Baetidae, in spite of being a simple parameter, was a valid indicator of water quality. In this study it was possible to verify that not all species have the same response to impacts, and it was possible to identify which species were associated to unimpaired and impaired areas.

Based on the distributional pattern of baetid species and as verified in the CCA ordination, species could be assigned to one of the five tolerance classes: 'Very sensitive' for those restricted to unimpaired sites; 'sensitive' for those predominantly associated to areas of classes 1 and 3 (high CCA values and dissolved oxygen concentration); 'somewhat sensitive' for those well represented in classes 2 site; 'tolerant' for those found with high abundance in sites of class 4 and the most impaired sites (I and J); and 'very tolerant' for those restricted to impaired sites (Fig. 1).

Members of the baetids observed in this study assigned to the not 'very tolerant' class. Since these species are frequently associated with pebbles substrates, in this study one of the main factors restricting baetid distribution was the high sedimentation observed in sites of classes 4 . Tolerance classification, together 
with information on the preferred substrate of each species, is a first approach towards a biological monitoring program considering species-level in tropical region.

In a time where rapid bioassessment tools are growing in importance, analyses at family or order level are often preferred, because of difficulties on taxonomy and better costeffectiveness ratio (Resh, 1995; Barbour et al., 1999). However, information on lower taxonomic levels allows complementary refined results for specific responses, especially in the chronically misleading 'intermediately impaired sites'. The advantages of using a species-level approach were clear with the two species of Labiobaetis. (For instance, Labiobaetis sp. occurred in pebbles substrates, while $L$. soldani occurred in grasses areas), and have different tolerance to the measured stress (90\% of individuals of Labiobaetis sp. occurred in the two least impaired sites, while L. soldani occurred with higher abundance at intermediately impaired sites and seem to be the only baetid species able/88 to live in the most impaired site in this study.

In conclusion, the present study corroborates wit earlier report that the members of the family Baetidae are the bio-indicators indicator of water quality and ecosystem health primarily because of presence in both the polluted and unpolluted reaches of the two River basins. However, they are sensitive to pollution as species richness and numbers are significantly reduced at downstream sites. The genus $C$. bimaculatum and $P$. regularum are tolerant to organic pollution. This study reveals that assemblages of species of Baetidae, responded to changes in substrate composition, habitat and water quality. The results of this study highlight the regional diversity and distribution of Baetidae in the Western Ghats streams and rivers. However, research involving the entire benthic macroinvertebrates will be better to understand overall structure and function of streams and rivers of the Western Ghats with special reference to bio-assessment aspects.

\section{Acknowledgements}

The authors are grateful to Prof. K. G. Sivaramakrishnan for constant support and encouragement for constructive criticism in preparation of this manuscript. Authors thank to Ministry of Environment, Forest and Climate Change, Government of India, New Delhi and Director, Zoological Survey of India, Kolkata for giving permission, facilities and encouragement for preparation of manuscript. Murali Krishnan greatly acknowledged to MHRD, Government of India, New Delhi for providing financial support and to Arun Nagendran and Pandiaraja for giving permission to field trips during the present study.

\section{References}

Allan, D. J. 1995. Stream Ecology: Structure and function of running water. Chapman and Hall Madras. Pp388.

Armitage, P. D., D. Moss, J. F. Wright and Furse, M. T. 1983. The performance of a new biological water quality score system based on macro-invertebrates over a wide range of unpolluted running-water sites. Water Research. 17: 333-347.

Balasubramanian, C., K. Venkataraman and Sivaramakrishnan, K.G. 1992. Bioecological studies on the burrowing mayfly Ephemera nadinae McCafferty and Edmunds 1973 (Ephemeroptera: Ephemeridae) in Kurangani stream. J. Bambay Nat. His. Soc. 89: 72-77.

Barbour, M. T., J. Gerritsen. J., S.D. Snyder and Stribling, J. B. 1999. Rapid bioassessment protocols for use in streams and wadeable Rivers: Periphyton, benthic macroinvertebrates, and fish (2nd edn.). Washington: EPA 841-B-99- 002. U.S. 
Environmental Protection Agency - Office of Water.

Bode, A., M. Varela., E. Fernandez., R. G. Quiros, and Anadon, R. 1995. Shelf-break Fronts Related to Poleward Currents in the Iberian Coast: Effects on Plankton Dynamics. First JGOFS International Scientific Symposium. Villefranche-surMer. France. 8-12.

Buss, D. F. 2001. Utilizando macroinvertebrados no desenvolvimento de um procedimento integrado de avaliação da qualidade da agua de rios. MS Dissertation. PPGE-UFRJ, Rio de Janeiro. ix $+132 p$.

Buss, D. F., and Salles, F. F. 2007. Using Baetidae Species as Biological Indicators of Environmental Degradation in a Brazilian River Basin. Environ. Monit. Assess. 130: 365-372.

Buss, D. F., D. F. Baptista., M. P. Silveira., J. L. Nessimian and Dorville, L. F. M. 2002. Influence of water chemistry and environmental degradation on macroinvertebrate assemblages in a River basin in south-east Brazil. Hydrobiologia. 481: 125-136.

Callisto, M., F. A. Esteves., J. F. Gonçalves and Fonseca J. J. L. 1998. Benthic macroinvertebrates as indicators of ecological fragility of small rivers ('igarapés') in a bauxite mining region of Brazilian Amazonia. Amazoniana. 15(1), 1-9.

Corkum, L. D. 1989. Patterns of benthic invertebrate assemblages in rivers of northwestern North America. Freshwater Biology. 21: 191-205.

Dudgeon, D. 1992. Endangered Ecosystems: a review of the conservation status of tropical Asian rivers. Hydrobiologia. 248:167-191.

Dudgeon, D. 1999. Tropical Asian Streams Zoobenthos, Ecology and Conservation. Honk Kong University Press. 830.

EEA. 2007. Land-use scenarios for Europe: qualitative and quantitative analysis on a European scale. In: EEA Technical Report No 9 (ed. EEA). EEA, Copenhaguen, Pp78.
Francischetti, C. N., F. F. Salles, E.R. Da-Silva. and Nessimian, J. L. 2004. A Efemeropterofauna (Insecta: Ephemeroptera) do trecho ritral inferior do Rio Campo Belo, Itatiaia, RJ: composição e mesodistribuição. Lundiana. 5(1), 33-39.

Hammer, Ø., D. A. T. Harper. and Ryan, D. D. 2001. PAST: Paleontological Statistics Software Package for Education and Data analysis. Paleontologia Electronica 4 (1), Pp 9.

Hilsenhoff, W. L. 1988. Rapid field assessment of organic pollution with a family-level biotic index. Journal of North American Benthological Society. 7(1): 65-68.

Jowett, I. G., Richardson, J., Biggs, B. J. F., Hickey, C and Quinn, J. M. 1991. Microhabitat preferences of benthic invertebrates and the development of generalised Deleatidium spp. habitat suitability curves, applied to four New Zealand Rivers. New Zealand Journal of Marine and Freshwater Research. 25: 187199.

Kubendran, T., T. Rathinakumar., C. Balasubramanian., C. Selvakumar and Sivaramakrishnan, K. G. 2014. A new species of Labiobaetis Novikova and Kluge 1987 (Ephemeroptera: Baetidae) from southern Western Ghats of India, with comments on the taxonomic status of LabioBaetis. Journal of Insect Science. 14 (86) 1-10.

Kubendran, T., Balasubramanian, C., Selvakumar, C. Gattolliat, J-L and Sivaramakrishnan, K. G. 2015. Contribution to the knowledge of Tenuibaetis Kang and Yang 1994, Nigrobaetis Novikova and Kluge 1987 and Labiobaetis Novikova and Kluge 1987 (Ephemeroptera: Baetidae) from the Western Ghats (India). Zootaxa. 3957 (2): 188-200.

Kubendran T., Ramesh M. 2016. Monitoring of adult aquatic insect activities and ecological role in the riparian zone of streams in the Western Ghats, India. IRAInternational Journal of Applied Science. 4(3): 460-470. 
Kubendran T. Ramesh M. 2016. Composition and distribution of aquatic insect communities in relation to water quality in two freshwater streams of southern Western Ghats, India. Journal of Entomology and Zoology Studies. 4(5): 689-695.

Martin, P., M. A. Hanifa and Arunachalam, M. 2000. Abundance and diversity of macroinvertebrates and fish in the Tamiraparani River, South India. Hydrobiologia. 430: 59-75.

Moulton, T. P., M. L. Souza., R. M. L. Silveira and Krsulovic, F. A. M. 2004. Effects of Ephemeropterans and shrimps on periphyton and sediments in a coastal stream (Atlantic forest, Rio de Janeiro, Brazil). Journal of the North American Benthological Society. 23(4), 868-881.

Resh, V. H. 1995. Freshwater benthic macroinvertebrates and rapid assessment procedures for water quality monitoring in developing and newly industrialized countries. In W. S. Davis and T. P. Simon (Eds.), Biological assessment and criteria: Tools for water resources planning and decision making (Pp 167-177). Boca Raton: Lewis.

Rosenberg, D. M., and Resh, V. H. 1993. Freshwater Monitoring and Benthic Macroinvertebrates. Chapman and Hall Publishers, New York.

Saunders, D. L., J. J. Meeuwing and Vincent, A. C. J. 2002. Freshwater protected areas: Strategies for conservation. Cons. Boil. 16(1): 30-41.

Selvakumar, C., S. Sundar and Sivaramakrishnan, K. G. 2012. Two new mayfly species (Baetidae) from India. Orienal Insects.46 (2): 116-129.

Silveira, M. P., D. F. Buss, J. L. Nessimian, M. Egler and Baptista, D. F. 2005. Application of biological measures for stream integrity assessment in South-East Brazil. Environmental Monitoring and Assessment. 101: 117-128.

Sivaramakrishnan, K. G., and Venkataraman, K. 1987. Observations on feeding properties, growth rate and fecundity in mayflies. Proc. Indian Acad. Sci. (Anim. Scie.). 96, (3): 305-309.

Sivaramakrishnan, K. G., K. A. Subramanian, V. V. Ramamoorthy, R. M. Sharma and Kailash Chandra. 2009. Checklist of Ephemeroptera of India. E-publication, Zoological Survey of India, Calcutta.

Subramanian, K. A., and K. G. Sivaramakrishnan. 2005. Habitat and microhabitat distribution of stream insect communities of the Western Ghats. Current Science. 89(6): 976: 987.

Subramanian, K. A. and K. G. Sivaramakrishnan. 2009. A new species of Symbiocloeon (Ephemeroptera: Baetidae) associated with a freshwater mussel species from India. Oriental Insect. 43: 7176.

Subramanian, K. A. K. G. Sivaramakrishnan and Gadgil, M. 2005. Impact of riparian landuse on stream insects of Khudremukh National Park, Karnataka state. India. Journal of Insect Science. 5: 49.

Vinson, M. R., and C. P. Hawkins. 1998. Biodiversity of stream insects: Variation at local and regional scales. Ann. Rev. Entomol. 43: 271-293.

\section{How to cite this article:}

Kubendran, T., C. Selvakumar, Avtar Kaur Sidhu, Akhil Nair and Murali Krishnan, S. 2017. Baetidae (Ephemeroptera: Insecta) as Biological Indicators of Environmental Degradation in Tamiraparani and Vaigai River Basins of Southern Western Ghats, India. Int.J.Curr.Microbiol.App.Sci. 6(6): 558-572. doi: https://doi.org/10.20546/ijcmas.2017.606.066 